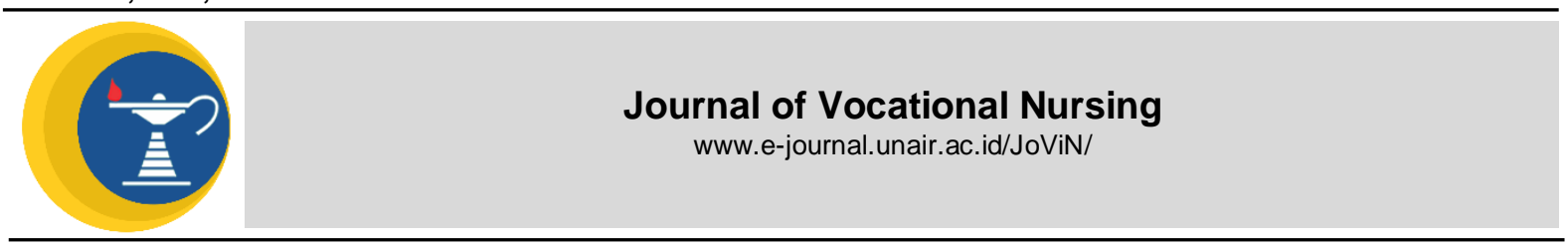

\title{
THE RELATIONSHIP OF KNOWLEDGE ABOUT COVID-19 WITH COMMUNITY PERCEPTIONS OF THE COVID-19 VACCINATION PROGRAM
}

\author{
Ninik Murtiyani, Yulianto, Lailatul Adhimah
}

Research Report

Nursing Academy Dian Husada Mojokerto

\section{A B STRACT}

Introduction: There are so many issues that affect information about the Covid-19 vaccine, such as safety and vaccines that have not been proven to be effective in preventing someone from being infected with Covid-19 again. Knowledge will also affect the public's perception of the Covid-19 vaccination program. Methods: The design of this study is a cross sectional approach. with a population of 127 respondents and a sample of 96 people. The sampling method uses simple random sampling, data collection uses a questionnaire. The research location is in Sumari Village, Sitting Sampeyan District, Gresik. The variables in this study are the dependent variable on the perception of the Covid-19 vaccination program in the community and the independent variable on knowledge about Covid-19. Data analysis using statistical test Spearman Rho test with $a=0.05$. ResultsRespondents' knowledge (88.5\%) is good knowledge. Respondents' perception of the COVID-19 vaccination program (90.6\%) was positive. The results of the spearman rho test show $\rho=0.018<a=0.05$ which means that there is a relationship between knowledge about covid-19 and the perception of the covid-19 vaccination program in the people of Sumari Village, Duduksampeyan district, Gresik. Conclusion: There is a relationship between knowledge about Covid-19 and the perception of the Covid-19 vaccination program in the community in Sumari Village, Duduksampeyan District, Gresik.

\section{ARTICLE INFO}

Received October 17, 2021

Accepted October 27, 2021

Online October 31, 2021

*Correspondence:

Ninik Murtiyani

*Email:

ninik.akbar@yahoo.co.id

Keywords:

Covid, Programs, Vaccinations

\section{INTRODUCTION}

The world health problem that is currently in the spotlight and is very important to get the attention of health scientists and the general public is the disease caused by the coronavirus. Corona Virus Disease - 19 or more popularly known as COVID-19 has been designated by WHO (World Health Organization) or the World Health Organization as a Public Health Emergency of World Concern (KMMD) on January 30, 2020, and finally designated as a Pandemic on the 11th. March 2020. In Indonesia, the first confirmed case of COVID-19 was on March 2, 2020, with two cases (Nurani et al., 2020). In May 2020, the death rate also continued to occur even though it was offset by the number of recovered patients. One of the programs that have also started to be carried out is the Covid-19 vaccination program

Globally, there were $172,427,800$ cases of COVID-19 with 3,731,634 deaths (WHO Report, 2021). The Covid-19 task force reported that $17,299,617$ total specimens were examined and $11,633,720$ total people were examined. For the East Java region, 156,326 (8.4\%) cases of COVID-19 were reported. Until early June 2021, a total of 2,121,290,083 doses of vaccine have been administered and $457,724,335$ people have been completely vaccinated Data in Indonesia reported that the number of people who had received the 1st vaccination was $17,775,918$ people and $11,197,069$ people who received the second vaccination. Lack of knowledge about covid-19 vaccination so that people think that the vaccine used can cause other health problems, there is no guarantee of safety and the vaccine has not been proven effective to prevent someone from being infected with COVID-19 again.

Coronavirus can cause mild to severe symptoms. There are at least two types of coronavirus that are known to cause disease in humans, namely Middle East Respiratory Syndrome (MERS-CoV) and Severe Acute Respiratory Syndrome (SARS-CoV). On 
February 11, 2020, WHO announced the official name of this new disease, namely "COVID-19" (Coronavirus Disease 2019) which is listed in the International Classification of Diseases (ICD). SARS-CoV-2 infection in humans causes symptoms of acute respiratory distress such as fever, cough, and shortness of breath. In severe cases, the disease can cause pneumonia, acute respiratory syndrome, kidney failure, and even death. The COVID-19 vaccination program is very important for individuals to create immunity against the Covid-19 virus. Several types of Covid-19 vaccines used in Indonesia include Pfizer, Sinovac, Moderna, Oxford/AstraZeneca, Novavax, Sinopharm, Merah Putih - BioFarma, and Sputnik V. covid-19 infection so that individuals must continue to apply health protocols strictly (Islamy, 2021)

Efforts to break the chain of the spread of COVID-19 require good understanding and knowledge from all elements, including the community. In the case of the COVID-19 pandemic in Indonesia, public knowledge about COVID-19 is very much needed as the basis for the community in showing COVID-19 prevention behavior. Knowledge will also affect the public's perception of the COVID-19 vaccination program. When people have a positive perception of the covid-19 vaccination program, people will consciously follow the covid-19 vaccination program carried out by the government to break the chain of covid-19 spread in Indonesia.

\section{MATERIALS AND METHODS}

In this study, the researcher used a correlational analytic design with a cross sectional approach. The population in this study was the entire community of RT.01 RW.01 in Sumari Hamlet, Sumari Village, DuduksampeyanDistrict, Gresik as many as 127 residents. The sample of this study was part of the community of RT.01 RW.01 in Sumari Hamlet, Sumari Village, Duduksampeyan District, Gresik Regency who met the research criteria as many as 96 respondents. The sampling design used simple random sampling. The variables in this study are knowledge about covid-19 and perceptions of the covid-19 vaccination program in the community. The instrument used is a questionnaire. The statistical test used in this study was the Spearman Rho test with a significance level of $a=0.05$

\section{RESULTS}

\section{Knowledge about Covid-19}

Table 1. Distribution of knowledge respondents about Covid-19 in Sumari Hamlet, Sumari Village, Duduksampeyan District, Gresik Regency

\begin{tabular}{lcc}
\hline Knowledge & Frequency & Percentage \\
\hline Good & 85 & 88,5 \\
Enough & 6 & 6,3 \\
Less & 5 & 5,2 \\
\hline Quantity & 96 & 100 \\
\hline
\end{tabular}

Perception of the Covid-19 vaccination program in the community

Table 2. Distribution of respondents based on the perception of the Covid-19 vaccination program in the community in Sumari Hamlet, Sumari Village, Duduksampeyan District, Gresik

\begin{tabular}{lcc}
\hline Perception & Frequency & Prosentase (\%) \\
\hline Positif Perception & 87 & $90,6 \%$ \\
Negatif Perception & 12 & 12,4 \\
\hline Quantity & 96 & 100 \\
\hline
\end{tabular}

Relationship of Knowledge about Covid-19 with Perception of the Covid-19 vaccination program in the community in Sumari Hamlet, Sumari Village, Duduksampeyan District, Gresik

Table 3 Cross Tabulation of Knowledge about Covid-19 with Perception of the Covid-19 vaccination program in the community in Sumari Hamlet, Sumari Village, Duduksampeyan District, Gresik Regency

\begin{tabular}{ccccccccc}
\hline Knowledge & \multicolumn{2}{c}{ Good } & \multicolumn{2}{c}{ Enough } & \multicolumn{2}{c}{ Less } & \multicolumn{2}{c}{ Quantity } \\
\hline Perception & $\mathrm{n}$ & $\%$ & $\mathrm{n}$ & $\%$ & $\mathrm{n}$ & $\%$ & $\mathrm{n}$ & $\%$ \\
\hline Positif & 87 & 0,6 & 0 & 0 & 0 & 0 & 87 & 90,6 \\
Negatif & 2 & 2 & 10 & 0,4 & 0 & 0 & 12 & 10,4 \\
\hline Sparman rank & \multicolumn{3}{c}{$\rho=0,000$} & \multicolumn{3}{c}{ Koef. Korelasi $=0,00$} \\
\hline
\end{tabular}




\section{DISCUSSION}

From table 1, it is found that most respondents know Covid-19 as many as 85 respondents (88.5\%). According to Notoatmodjo (Darsini et al., 2019) a person's knowledge of an object has a different intensity or level. Broadly speaking, it is divided into 6 levels of knowledge, namely:(1) Know, (2) Understand. (3) Application (Application). (4) Analysis (Analysis), (5) Synthesis (Synthesis). (6) Evaluation (Evaluation). The higher the education, the higher the knowledge. The higher a person's education, the easier it is to receive information so that there is a lot of knowledge. Village midwives and village nurses Sumari Village, are very important for the community to need to increase knowledge about COVID-19 and the COVID-19 vaccination program is required to always provide health education counseling about the importance of participating in the Covid-19 vaccination program held by the government.

Table 2 shows that most of the respondents have positive perceptions as many as 87 respondents (90.6\%). Everyone has their perception of what they think, see and feel. This also means that perception determines what a person will do to fulfill various interests, both for himself, his family, and the community in which he interacts. This perception is what distinguishes one person from another. Perception is generated from the concretization of thoughts, then gives birth to different concepts or ideas from each person even though the object seen is the same. Perception is a sensing process, namely the process of receiving a stimulus by an individual through the senses or also called a sensory process. This process does not just stop, but the stimulus is continued and the next process is a perception process. Therefore the perception process cannot be separated from the sensing process, which is a preliminary process of the perception process (Ari \& Astiti, 2014)

Table 3 above shows that most of the respondents have a positive perception $(90.6 \%)$ and most of the respondents have good knowledge (90.6\%). correlation $\rho=0.000$ means that there is a relationship between knowledge about Covid-19 and the perception of the Covid-19 vaccination program in the community in Sumari Village, Duduksampeyan District, Gresik. This is closely related that a person's knowledge is influenced by the perceptions that exist in the individual himself. Knowledge is a result of curiosity through sensory processes, especially in the eyes and ears of certain objects. Knowledge is an important domain in the formation of open behavior (Donsu et al., 2014). Knowledge or knowledge is the result of human sensing or the result of knowing someone about an object through their five senses. The five human senses for sensing objects are sight, hearing, smell, taste, and touch. Increased knowledge is not obtained from formal education, but can also be obtained from non-formal education. Knowledge of an object contains two aspects, namely positive aspects and negative aspects. These two aspects will determine a person's attitude. The more positive aspects and objects that are known, the more positive attitudes will be towards certain objects(Darsini et al., 2019).

Perception is a process of recognizing or identifying something using the five senses (Ari \& Astiti, 2014). perception is the essence of communication. Perception has a very important role in the success of communication. That is, accuracy in perceiving sensory stimuli leads to successful communication. On the other hand, failure to perceive the stimulus causes miscommunication(Ari \& Astiti, 2014). One of the factors that influence a person's perception is education. Notoatmodjo explained that people who have higher education will give more rational responses than people with low education or no education at all. Another factor that influences perception is experience and information. More information can influence or increase one's knowledge and with knowledge raises awareness that eventually someone will behave in accordance with the knowledge they have (Lubis et al., 2017). Experience is an event that has been experienced by someone. Not only an experience at all with an object tends to be negative towards a particular object, to be a basis for forming an attitude, personal experience must leave a strong impression. Attitudes will be more easily formed if the personal experience occurs in situations that involve emotions, appreciation will be deeper and imprint(Lubis et al., 2017).

\section{CONCLUSION}

There is a relationship between knowledge about covid-19 and the perception of the covid-19 vaccination program in the community in Sumari Hamlet, Sumari Village, Duduksampeyan District, Gresik with a strong relationship strength.

\section{REFERENCES}

Ari, I. A. G. R. P., \& Astiti, D. P. (2014). Peran Persepsi Individu Terhadap Asuransi dan Model Kepercayaan Kesehatan dalam Pengambilan Keputusan Menggunakan 
Asuransi Jiwa. Jurnal Psikologi Udayana, 1(2), 381-388. https://doi.org/10.24843/jpu.2014.v01.i02 .p17

Darsini, D., Fahrurrozi, F., \& Cahyono, E. A. (2019). PENGETAHUAN; ARTIKEL REVIEW. Jurnal Keperawatan, 12(1), 13.

Donsu, J. D., Hadjam, M. N. R., Asdie, A. H., \& Hidayat, R. (2014). Peran Faktor-faktor Psikologis terhadap Depresi pada Pasien Diabetes Mellitus Tipe 2. Jurnal Psikologi, 41(2),

241. https://doi.org/10.22146/jpsi.6953

Islamy, Y. (2021). Urgensi Pengaturan Trading in Influence Sebagai Sarana Pembangunan Masyarakat. DiH: Jurnal IImu Hukum, 17(1). https://doi.org/10.30996/dih.v17i1.4132

Lubis, M., Kartiwi, M., \& Zulhuda, S. (2017). Privacy and personal data protection in electronic voting: Factors and measures. Telkomnika (Telecommunication Computing Electronics and Control), 15(1), 512-521. https://doi.org/10.12928/TELKOMNIKA.v $15 \mathrm{i} 1.3804$

Nurani, N., Nursjanti, F., \& Munawar, F. (2020). Penyuluhan Sertifikasi Halal Bagi UMKM Jawa Barat Pada Situasi Pandemi Covid19. Madaniya, 1(3), 126-139. https://madaniya.pustaka.my.id/journals/c ontents/article/view/24 